\title{
Inheritance of traits associated with seed size in groundnut (Arachis hypogaea L.)
}

\author{
R. Venuprasad $\cdot$ R. Aruna $\cdot$ S. N. Nigam
}

Received: 21 December 2010/ Accepted: 9 February 2011/Published online: 19 February 2011

(C) Springer Science+Business Media B.V. 2011

\begin{abstract}
Inheritance of groundnut (Arachis hypogaea L.) seed traits particularly seed weight, seed length, seed width and length:width ratio was explored in this study. Six-generation mean analysis was carried with two groundnut crosses and their reciprocals in 2 years. Groundnut genotypes significantly differing in seed sizes were used as parents. Highly significant reciprocal differences were observed for almost all the traits in $\mathrm{F}_{1}, \mathrm{~F}_{2}$, and $\mathrm{BC}$ generations. Additive genetic effects were highly significant and explained majority of the variation in these traits. Results suggest that the seed size traits studied in this study were controlled both by combination of both maternal and nuclear gene effects. All the four seed traits measured were highly correlated suggesting that they could be simultaneously improved. Significance of additive effect in all the four crosses suggests that effective selection for seed size traits could be practiced in early generations. In breeding program for confectionary traits it is essential to include a large-seeded genotype as the female parent to exploit the maternal effects.
\end{abstract}

Venuprasad and Aruna-Formerly ICRISAT staff.

R. Venuprasad · R. Aruna · S. N. Nigam ( $₫)$

ICRISAT Center, Patancheru 502 324,

Andhra Pradesh, India

e-mail: s.nigam@cgiar.org
Keywords Arachis hypogaea L. · Confectionary · Seed size · Maternal effect · Groundnut breeding

\section{Introduction}

Groundnut is an important oilseed legume crop. It is also valued as a rich source of protein, minerals and vitamins. In the past two decades in India, the demand for groundnut oil is on the decline because of its high cost and due to growth of other conventional and nonconventional vegetable oils. But at the same time in recent years importance of groundnut as a food crop (confectionary) is growing. In confectionery groundnuts, quality of seed is an important consideration. Various physical, sensory, chemical, and nutritional factors determine the quality of confectionery groundnut. Groundnut with large seed, low oil but with high oleic acid/linoleic acid (O/L) ratio is preferred for direct consumption. Importance of various quality traits and their variability has been reviewed elsewhere (Dwivedi and Nigam 2005). Among others, seed size is the most important physical quality trait that attracts consumers' immediate attention.

As reported by many, the pod size and seed size in groundnut are positively correlated but the degree of relationship varies. However, the relationship between pod size and shelling outturn is not always positive and thus there is limited success in developing varieties bearing large pods with high shelling outturn (de Godoy and Norden 1981). Hence, to develop varieties 
suitable for confectionery purposes there is a need to treat seed size as a separate trait.

Several reports on inheritance of pod and seed size in groundnut exist in literature and are conflicting [a review of early studies is given by Hammons (1973)]. While some report large pod and seed size to be dominant to small pod and seed (for example, Balaiah et al. 1977; Layrisse et al. 1980) others claim small pods to be dominant over large pods (example, Cahaner 1978). Seed size is also reported to be under control of single gene (Balaiah et al. 1977), three genes (Pattanashetti et al. 2008) and also five genes (Martin 1967). While several others report quantitative inheritance with predominance of additive gene action for pod and seed traits (Garet 1976; Mohammed et al. 1978; Layrisse et al. 1980; Swe and Branch 1986; Anderson et al. 1993). Contradictory results with regards to the relative importance of additive, non additive and epistatic effects in determining seed size are reported (Nadaf et al. 1988; Upadhyaya et al. 1992; Vindhiya Varman and Paramasivam 1992; Vindhiya Varman and Thangavelu 1999). Maternal influence in determining seed size is also reported (for example, de Godoy and Norden 1981; Hammons and Branch 1981; Dwivedi et al. 1989; Hariprasanna et al. 2008).

The large discrepancies in reported studies could be because genetic studies of seed size are often conducted using populations that are not significantly different in seed size (de Godoy and Norden 1981). Use of parents that differ significantly for the trait in question should produce better understanding of how these traits would behave in segregating generations. Most of the above studies were conducted using combining ability analysis and rarely by generation means analysis. Even though some studies report presence of maternal effects, limited use of reciprocal populations is made in these studies and again, this could cause discrepancies between studies. The purpose of this study was to study inheritance of seed size through generation means analysis using parents that widely differ for seed size. Reciprocal populations were studied to explore the involvement of maternal influence. And further, to know the stability the experiment was repeated in two seasons.

\section{Materials and methods}

The study was conducted at ICRISAT Center, Patancheru, India. Two crosses including their reciprocals (Chico $\times$ ICGV 01393, ICGV $01393 \times$ Chico, Chico $\times$ ICGV 02251 and ICGV $02251 \times$ Chico) were used in the study. Chico is a smallseeded Spanish germplasm from USA with hundred seed weight (HSW of $\sim 27 \mathrm{~g}$ while ICGV 01393 (HSW $\sim 62 \mathrm{~g}$ ) and ICGV 02251 (HSW $\sim 64 \mathrm{~g}$ )) are ICRISAT bred large-seeded varieties (advanced generation breeding lines) suited for confectionery purposes. In each of the cross the following generation progenies were obtained: $\mathrm{F}_{1}, \quad \mathrm{~F}_{2}, \quad \mathrm{BC}_{1} \mathrm{P} 1$ $\left(\mathrm{F}_{1} \times \mathrm{P} 1\right)$, and BC1 P2 $\left(\mathrm{F}_{1} \times \mathrm{P} 2\right)$. During the postrainy seasons of 2006-2007 and 2007-2008, these eight generation progenies of each cross along with their parents were screened in replicated trials under field conditions.

The experimental material in each cross was planted on ridges $60 \mathrm{~cm}$ apart and between plants within a ridge $10 \mathrm{~cm}$ spacing in a split plot design with two replications in an Alfisol field. The row length was $4 \mathrm{~m}$. The parents and $\mathrm{F}_{1}$ 's were grown on single rows, each backcross generation in two rows and the $F_{2}$ 's in five rows. Trials were irrigated by furrow method. Standard agronomic practices were followed to raise a healthy crop. At maturity, groundnuts were harvested from all plants separately in all the generations (parents, $\mathrm{F}_{1}, \mathrm{~F}_{2}, \mathrm{BC}_{1}, \mathrm{BC}_{2}$ and their reciprocals) and shelled. Immature seeds were discarded and total number of well developed seeds and its total weight in $\mathrm{g}$ were recorded for each plant. For seed length and width measurements, ten seeds from each sample were randomly taken and average seed length and width were recorded.

The statistical analysis was performed using SAS. Reciprocal differences were tested by $t$-test. The means and variances from individual plant data were estimated for every generation separately and generation mean analysis were performed as explained in Singh and Chaudhary (1985). Scaling tests (Mather 1949) were performed. Joint scaling test (Cavalli 1952) was conducted to estimate the genetic components and digenic interactions among these components, viz, $m$ (mean), $d$ (pooled additive effects) and $h$ (pooled dominance effects). This model was tested for goodness of fit by the chi-square test to determine if linkage in higher order interaction was present (Mather and Jinks 1982). If the chi-square test was significant a six-parameter model was fitted to the generation means which in addition to $m$, $d$, and $h$ included $i$ (pooled additive $\times$ additive 
epistatic effects), $j$ (pooled additive $\times$ dominance epistatic effects) and $l$ (pooled dominance $\times$ dominance epistatic effects). After fitting the six parameter model if any of the effect was non-significant then they were eliminated from the model and the remaining effects were re-estimated. Significance of the re-estimated model was tested by chi-square tests using appropriate degrees of freedom. Contribution made by each parameter in explaining the variation for a trait was obtained using the sum of squares method.

\section{Results}

The mean values of different generations are presented in Table 1. Chico the small seeded parent consistently produced small seeds $\left(0.26 \mathrm{~g} \mathrm{seed}^{-1}\right.$ on average) while the large seeded parents, ICGV 01393 and ICGV 02251, consistently produced large seeds (on average 0.62 and $0.64 \mathrm{~g} \mathrm{seed}^{-1}$, respectively). The large-seeded parents also had longer seed length, wider seed width and a higher length:width ratio than Chico. Transgressive segregation was observed in all

Table 1 Mean values of seed traits in different generations of three groundnut crosses

\begin{tabular}{|c|c|c|c|c|c|c|c|c|}
\hline \multirow[t]{3}{*}{ Trait/generation } & \multicolumn{8}{|l|}{ Cross/year } \\
\hline & \multicolumn{2}{|c|}{ Chico $\times$ ICGV01393 } & \multicolumn{2}{|c|}{ ICGV01393 × Chico } & \multicolumn{2}{|c|}{ Chico $\times$ ICGV02251 } & \multicolumn{2}{|c|}{ ICGV02251 × Chico } \\
\hline & 2006-2007 & 2007-2008 & $006-2007$ & 2007-2008 & 2006-2007 & 2007-2008 & 2006-2007 & 2007-2008 \\
\hline \multicolumn{9}{|c|}{ Seed weight (per seed, g) } \\
\hline $\mathrm{P} 1$ & $0.25 \pm 0.01$ & $0.26 \pm 0.02$ & $0.67 \pm 0.03$ & $0.57 \pm 0.05$ & $0.25 \pm 0.01$ & $0.25 \pm 0.02$ & $0.59 \pm 0.02$ & $0.61 \pm 0.03$ \\
\hline $\mathrm{P} 2$ & $0.61 \pm 0.02$ & $0.62 \pm 0.04$ & $0.27 \pm 0.02$ & $0.25 \pm 0.04$ & $0.69 \pm 0.03$ & $0.65 \pm 0.03$ & $0.31 \pm 0.02$ & $0.24 \pm 0.01$ \\
\hline $\mathrm{F}_{1}$ & $0.30 \pm 0.03$ & $0.32 \pm 0.02$ & $0.53 \pm 0.04$ & $0.53 \pm 0.08$ & $0.31 \pm 0.02$ & $0.36 \pm 0.02$ & $0.42 \pm 0.02$ & $0.39 \pm 0.04$ \\
\hline $\mathrm{F}_{2}$ & $0.34 \pm 0.01$ & $0.39 \pm 0.02$ & $0.41 \pm 0.01$ & $0.61 \pm 0.02$ & $0.28 \pm 0.01$ & $0.35 \pm 0.01$ & $0.37 \pm 0.01$ & $0.50 \pm 0.02$ \\
\hline $\mathrm{F}_{1} \times \mathrm{P} 1$ & $0.26 \pm 0.01$ & $0.27 \pm 0.01$ & $0.53 \pm 0.03$ & $0.56 \pm 0.02$ & $0.32 \pm 0.01$ & $0.39 \pm 0.02$ & $0.36 \pm 0.02$ & $0.28 \pm 0.01$ \\
\hline $\mathrm{F}_{1} \times \mathrm{P} 2$ & $0.41 \pm 0.02$ & $0.45 \pm 0.01$ & $0.34 \pm 0.02$ & $0.37 \pm 0.02$ & $0.31 \pm 0.01$ & $0.32 \pm 0.02$ & $0.42 \pm 0.02$ & $0.50 \pm 0.02$ \\
\hline \multicolumn{9}{|c|}{ Seed length $(\mathrm{cm})$} \\
\hline $\mathrm{P} 1$ & $1.07 \pm 0.02$ & $1.10 \pm 0.03$ & $1.71 \pm 0.04$ & $1.57 \pm 0.05$ & $1.11 \pm 0.02$ & $1.05 \pm 0.03$ & $1.67 \pm 0.03$ & $1.58 \pm 0.04$ \\
\hline $\mathrm{P} 2$ & $1.74 \pm 0.03$ & $1.60 \pm 0.06$ & $1.11 \pm 0.02$ & $1.01 \pm 0.05$ & $1.69 \pm 0.02$ & $1.67 \pm 0.03$ & $1.10 \pm 0.01$ & $0.98 \pm 0.01$ \\
\hline $\mathrm{F}_{1}$ & $1.25 \pm 0.06$ & $1.27 \pm 0.03$ & $1.64 \pm 0.06$ & $1.40 \pm 0.04$ & $1.19 \pm 0.02$ & $1.31 \pm 0.03$ & $1.39 \pm 0.03$ & $1.37 \pm 0.05$ \\
\hline $\mathrm{F}_{2}$ & $1.24 \pm 0.02$ & $1.22 \pm 0.03$ & $1.41 \pm 0.02$ & $1.60 \pm 0.02$ & $1.17 \pm 0.01$ & $1.16 \pm 0.01$ & $1.36 \pm 0.01$ & $1.38 \pm 0.03$ \\
\hline $\mathrm{F}_{1} \times \mathrm{P} 1$ & $1.14 \pm 0.01$ & $1.05 \pm 0.02$ & $1.56 \pm 0.03$ & $1.59 \pm 0.03$ & $1.19 \pm 0.02$ & $1.18 \pm 0.02$ & $1.24 \pm 0.04$ & $1.05 \pm 0.01$ \\
\hline $\mathrm{F}_{1} \times \mathrm{P} 2$ & $1.44 \pm 0.03$ & $1.34 \pm 0.03$ & $1.29 \pm 0.04$ & $1.23 \pm 0.03$ & $1.19 \pm 0.02$ & $1.15 \pm 0.02$ & $1.36 \pm 0.03$ & $1.34 \pm 0.03$ \\
\hline \multicolumn{9}{|l|}{ Seed width $(\mathrm{cm})$} \\
\hline $\mathrm{P} 1$ & $0.66 \pm 0.01$ & $0.68 \pm 0.02$ & $0.89 \pm 0.02$ & $0.81 \pm 0.03$ & $0.67 \pm 0.01$ & $0.65 \pm 0.02$ & $0.87 \pm 0.01$ & $0.84 \pm 0.02$ \\
\hline $\mathrm{P} 2$ & $0.83 \pm 0.01$ & $0.84 \pm 0.03$ & $0.69 \pm 0.01$ & $0.56 \pm 0.03$ & $0.90 \pm 0.02$ & $0.90 \pm 0.02$ & $0.70 \pm 0.01$ & $0.64 \pm 0.01$ \\
\hline $\mathrm{F}_{1}$ & $0.72 \pm 0.03$ & $0.65 \pm 0.02$ & $0.79 \pm 0.03$ & $0.7 \pm 0.03$ & $0.71 \pm 0.01$ & $0.68 \pm 0.02$ & $0.78 \pm 0.01$ & $0.72 \pm 0.03$ \\
\hline $\mathrm{F}_{2}$ & $0.71 \pm 0.01$ & $0.71 \pm 0.01$ & $0.76 \pm 0.01$ & $0.84 \pm 0.01$ & $0.69 \pm 0.01$ & $0.73 \pm 0.01$ & $0.73 \pm 0.01$ & $0.79 \pm 0.01$ \\
\hline $\mathrm{F}_{1} \times \mathrm{P} 1$ & 0.01 & $0.67 \pm 0.01$ & $1 \pm 0.02$ & 0.02 & $2 \pm 0.01$ & \pm 0.01 & \pm 0.02 & $0.68 \pm 0.01$ \\
\hline $\mathrm{F}_{1} \times \mathrm{P} 2$ & $0.76 \pm 0.02$ & $0.75 \pm 0.01$ & $0.73 \pm 0.01$ & $0.71 \pm 0.02$ & $0.71 \pm 0.01$ & $0.68 \pm 0.01$ & $0.78 \pm 0.02$ & $0.80 \pm 0.02$ \\
\hline \multicolumn{9}{|c|}{ Seed length:seed width ratio } \\
\hline $\mathrm{P} 1$ & $1.63 \pm 0.02$ & $1.64 \pm 0.03$ & $1.93 \pm 0.03$ & $1.96 \pm 0.05$ & $1.67 \pm 0.03$ & $1.64 \pm 0.03$ & $1.93 \pm 0.03$ & $1.91 \pm 0.04$ \\
\hline $\mathrm{P} 2$ & $2.11 \pm 0.04$ & $1.90 \pm 0.04$ & $1.62 \pm 0.02$ & $1.80 \pm 0.04$ & $1.9 \pm 0.03$ & $1.87 \pm 0.03$ & $1.57 \pm 0.02$ & $1.55 \pm 0.04$ \\
\hline $\mathrm{F}_{2}$ & $1.73 \pm 0.06$ & $1.97 \pm 0.04$ & $2.08 \pm 0.05$ & $2.01 \pm 0.04$ & $1.68 \pm 0.03$ & $1.94 \pm 0.04$ & $1.78 \pm 0.03$ & $1.91 \pm 0.08$ \\
\hline $\mathrm{F}_{2}$ & $1.76 \pm 0.02$ & $1.72 \pm 0.03$ & $1.87 \pm 0.02$ & $1.92 \pm 0.02$ & $1.69 \pm 0.01$ & $1.61 \pm 0.02$ & $1.88 \pm 0.02$ & $1.77 \pm 0.04$ \\
\hline $\mathrm{F}_{1} \times \mathrm{P} 1$ & $1.70 \pm 0.04$ & $1.59 \pm 0.03$ & $1.95 \pm 0.05$ & $2.04 \pm 0.05$ & $1.67 \pm 0.01$ & $1.66 \pm 0.03$ & $1.69 \pm 0.03$ & $1.57 \pm 0.02$ \\
\hline $\mathrm{F}_{1} \times \mathrm{P} 2$ & $1.89 \pm 0.03$ & $1.80 \pm 0.03$ & $1.76 \pm 0.03$ & $1.74 \pm 0.04$ & $1.67 \pm 0.02$ & $1.69 \pm 0.02$ & $1.75 \pm 0.02$ & $1.67 \pm 0.02$ \\
\hline
\end{tabular}


the crosses in $F_{2}$ generation; the smallest seed recorded a weight of about $0.10 \mathrm{~g}$ while the largest seed weighed over $1.0 \mathrm{~g}$ (data not shown). Similarly, the shortest seed length was below $0.6 \mathrm{~cm}$ while the longest was over $1.6 \mathrm{~cm}$, and in seed width the smallest was below $0.40 \mathrm{~cm}$ while the largest was about $1.0 \mathrm{~cm}$. The length to width ratio of seed varied between 1 and 2.5 in different crosses. Anderson et al. (1993) also observed transgressive segregation for pod and seed size in their study.

Highly significant reciprocal differences were observed in most of the cases (Table 2). The differences were very clearly evident for seed weight and seed length traits and were stable in both the seasons.
Reciprocal differences were observed in $F_{1}, F_{2}$ and $\mathrm{BC}$ generations. All the four traits were highly correlated with one another in both the seasons (Table 3). Correlation between same traits in different seasons was also highly significant.

There was a good agreement between scaling tests (Table 4) and joint scaling tests (Table 5). The threegeneration model (consisting of $m, d$, and $h$ effects) was adequate in seven out of the 32 cases. Of these, five cases belonged to one single cross (Chico $\times$ ICGV 01393) and involved all the traits studied except seed length. For the rest of the cases, sixparameter model involving epistatic effects was fitted and was found adequate in 19 cases; in six cases

Table 2 Reciprocal differences for confectionery traits in groundnut

\begin{tabular}{|c|c|c|c|c|c|}
\hline \multirow[t]{2}{*}{ Trait } & \multirow[t]{2}{*}{ Generation } & \multicolumn{2}{|c|}{$\begin{array}{l}\text { Chico } \times \text { ICGV01393 vs. } \\
\text { ICGV01393 × Chico }\end{array}$} & \multicolumn{2}{|c|}{$\begin{array}{l}\text { Chico } \times \text { ICGV02251 vs. } \\
\text { ICGV02251 × Chico }\end{array}$} \\
\hline & & 2006-2007 & 2007-2008 & 2006-2007 & 2007-2008 \\
\hline \multirow[t]{4}{*}{ Seed weight } & $\mathrm{F}_{1}$ & 0.0002 & 0.02 & 0.04 & NS \\
\hline & $\mathrm{F}_{2}$ & $<0.0001$ & $<0.0001$ & $<0.0001$ & $<0.0001$ \\
\hline & $\mathrm{F}_{1} \times$ Chico & 0.0002 & 0.0001 & 0.0002 & 0.0008 \\
\hline & $\mathrm{F}_{1} \times$ large-seeded parent & 0.001 & 0.0001 & NS & 0.03 \\
\hline \multirow[t]{4}{*}{ Seed length } & $\mathrm{F}_{1}$ & 0.003 & 0.02 & 0.002 & NS \\
\hline & $\mathrm{F}_{2}$ & $<0.0001$ & $<0.0001$ & $<0.0001$ & $<0.0001$ \\
\hline & $\mathrm{F}_{1} \times$ Chico & 0.0001 & $<0.0001$ & $<0.0001$ & $<0.0001$ \\
\hline & $\mathrm{F}_{1} \times$ large-seeded parent & 0.02 & $<0.0001$ & NS & 0.001 \\
\hline \multirow[t]{4}{*}{ Seed width } & $\mathrm{F}_{1}$ & NS & NS & 0.04 & NS \\
\hline & $\mathrm{F}_{2}$ & $<0.0001$ & $<0.0001$ & 0.0004 & $<0.0001$ \\
\hline & $\mathrm{F}_{1} \times$ Chico & 0.002 & 0.02 & 0.0007 & $<0.0001$ \\
\hline & $\mathrm{F}_{1} \times$ large-seeded parent & NS & 0.04 & NS & NS \\
\hline \multirow{4}{*}{$\begin{array}{l}\text { Seed length:seed } \\
\text { width ratio }\end{array}$} & $\mathrm{F}_{1}$ & 0.007 & NS & 0.04 & NS \\
\hline & $\mathrm{F}_{2}$ & $<0.0001$ & $<0.0001$ & $<0.0001$ & $<0.0001$ \\
\hline & $\mathrm{F}_{1} \times$ Chico & NS & 0.003 & 0.001 & NS \\
\hline & $\mathrm{F}_{1} \times$ large-seeded parent & NS & $<0.0001$ & NS & 0.0002 \\
\hline
\end{tabular}

Table 3 Correlations between trait means of different generations in the postrainy seasons of 2006 (above diagonal) and 2007 (below diagonal) and between same trait in the two different seasons (diagonal)

\begin{tabular}{lllll}
\hline Trait & Seed weight & Seed length & Seed width & Length:width ratio \\
\hline Seed weight & $\mathbf{0 . 8 8 * * *}$ & $0.97 * * *$ & $0.98^{* * *}$ & $0.83 * * *$ \\
Seed length & $0.96^{* * *}$ & $\mathbf{0 . 9 1 * * *}$ & $0.95^{* * *}$ & $0.93 * * *$ \\
Seed width & $0.93^{* * *}$ & $0.90^{* * *}$ & $\mathbf{0 . 8 0 * * *}$ & $0.77 * * *$ \\
Seed length:seed width ratio & $0.67 * * *$ & $0.77^{* * *}$ & $0.43^{*}$ & $\mathbf{0 . 7 0 * * *}$ \\
\hline
\end{tabular}

*,*** Significant at $P \leq 0.05$ and 0.001 levels, respectively 
Table 4 Estimates of scaling test of seed traits in groundnut

\begin{tabular}{|c|c|c|c|c|c|c|c|c|c|}
\hline \multirow[t]{2}{*}{ Characters } & \multirow[t]{2}{*}{ Cross } & \multicolumn{4}{|c|}{ 2006-2007 postrainy season } & \multicolumn{4}{|c|}{ 2007-2008 postrainy season } \\
\hline & & A & B & $\mathrm{C}$ & $\mathrm{D}$ & A & B & $\mathrm{C}$ & $\mathrm{D}$ \\
\hline \multirow[t]{4}{*}{ Seed weight } & Chico $\times$ ICGV 01393 & -0.01 & -0.08 & -0.08 & 0.01 & -0.03 & -0.03 & 0.03 & 0.05 \\
\hline & ICGV $01393 \times$ Chico & -0.13 & $-0.13 *$ & $-0.36 * *$ & -0.05 & 0.03 & -0.04 & $0.58 * *$ & $0.29 * *$ \\
\hline & Chico $\times$ ICGV 02251 & $0.08 * *$ & $-0.37 * *$ & $-0.43 * *$ & $-0.07 * *$ & $0.16^{* *}$ & $-0.38 * *$ & $-0.23 * *$ & -0.01 \\
\hline & ICGV $02251 \times$ Chico & $-0.29 * *$ & 0.10 & $-0.26 * *$ & -0.04 & $-0.44 * *$ & $0.38 * *$ & $0.39 * *$ & $0.22 * *$ \\
\hline \multirow[t]{4}{*}{ Seed length } & Chico $\times$ ICGV 01393 & -0.04 & -0.12 & $-0.37 *$ & $-0.10^{*}$ & $-0.26 * *$ & $-0.18 *$ & $-0.35^{*}$ & 0.05 \\
\hline & ICGV $01393 \times$ Chico & $-0.24 *$ & -0.17 & $-0.46^{*}$ & -0.03 & $0.21 *$ & 0.05 & $1.04 * *$ & $0.39 * *$ \\
\hline & Chico $\times$ ICGV 02251 & 0.09 & $-0.51 * *$ & $-0.51 * *$ & -0.05 & -0.01 & $-0.68 * *$ & $-0.70 * *$ & 0.00 \\
\hline & ICGV $02251 \times$ Chico & $-0.58 * *$ & $0.24 * *$ & -0.11 & $0.11 *$ & $-0.84 * *$ & $0.32 * *$ & 0.20 & $0.36^{* *}$ \\
\hline \multirow[t]{4}{*}{ Seed width } & Chico $\times$ ICGV 01393 & -0.03 & -0.04 & -0.11 & -0.02 & 0.01 & 0.01 & 0.04 & 0.01 \\
\hline & ICGV $01393 \times$ Chico & -0.05 & -0.02 & -0.13 & -0.03 & 0.08 & $0.16^{* *}$ & $0.60 * *$ & $0.18 * *$ \\
\hline & Chico $\times$ ICGV 02251 & 0.06 & $-0.18 * *$ & $-0.21 * *$ & -0.04 & $0.10 * *$ & $-0.21 * *$ & 0.01 & 0.06 \\
\hline & ICGV $02251 \times$ Chico & $-0.20 * *$ & $0.08 *$ & $-0.23 * *$ & $-0.06^{*}$ & $-0.20 * *$ & $0.25 * *$ & $0.24 * *$ & $0.10 * *$ \\
\hline \multirow{4}{*}{$\begin{array}{l}\text { Seed length:seed } \\
\text { width ratio }\end{array}$} & Chico $\times$ ICGV 01393 & 0.04 & -0.05 & -0.17 & -0.08 & $-0.42 * *$ & $-0.28 * *$ & $-0.59 * *$ & 0.05 \\
\hline & ICGV $01393 \times$ Chico & -0.11 & $-0.18 *$ & -0.22 & 0.03 & 0.11 & $-0.33 * *$ & -0.09 & 0.06 \\
\hline & Chico $\times$ ICGV 02251 & -0.02 & $-0.23 * *$ & $-0.16^{*}$ & 0.05 & $-0.25 * *$ & $-0.43 * *$ & $-0.94 * *$ & $-0.13^{*}$ \\
\hline & ICGV $02251 \times$ Chico & $-0.32 * *$ & $0.16 * *$ & $0.45 * *$ & $0.31 * *$ & $-0.68 * *$ & -0.11 & -0.19 & $0.30 * *$ \\
\hline
\end{tabular}

*, ** Significant at $P \leq 0.05$ and 0.01 levels, respectively

neither of the two models was adequate. Mean $(m)$ and additive $(d)$ genetic effects were highly significant in almost all the cases. In crosses where the female parent was Chico (small-seeded), additive effects were always negative, irrespective of the trait, and always positive when the female parent was large-seeded. The negative sign of additive effect merely reflects which of the parents is chosen as P1 and has no genetic consequences. Dominance (h) effect was significant in all but ten cases and whenever significant direction was mostly negative. The negative sign of dominance effects indicates that in these crosses dominance effects were contributed by the parent having alleles responsible for low value of the trait i.e., Chico. Traits varied with respect to importance of epistatic components. For seed weight $i$ (additive $\times$ additive) component was highly significant in six out of eight cases and $j$ (additive $\times$ dominant) component was significant only in crosses involving ICGV 02251. While $l$ (dominance $\times$ dominance) was significant in seven out of eight cases for seed length, it was significant in only one out of eight cases for seed width. For seed width $i$ and $j$ were significant in at least in $50 \%$ of the cases while for length:width ratio $j$ and $l$ were significant in more than $50 \%$ of the cases. Whenever both $h$ and $l$ were significant, they always had opposite sign, this implies that duplicate interactions were present (Mather and Jinks 1982).

The percent contribution of individual genetic factors to trait variability is given in Table 6. Additive effects explained bulk of the variation in most cases; it contributed to as much as $97 \%$ of the variation. In contrast, dominance explained relatively low amounts of variation, the highest being 33\%. Among the epistatic components, $j$ effects explained higher variability than $i$ effects and $l$ effects were the least important. Dominance effects explained relatively larger variability in crosses where Chico was the female parent, similarly $j$ effects explained variation in crosses involving ICGV02251 as a parent.

\section{Discussion}

From the results it is evident that the confectionery traits studied in this study, seed weight, seed length, seed width and seed length:width ratio, were controlled both by maternal and nuclear effects. Maternal 


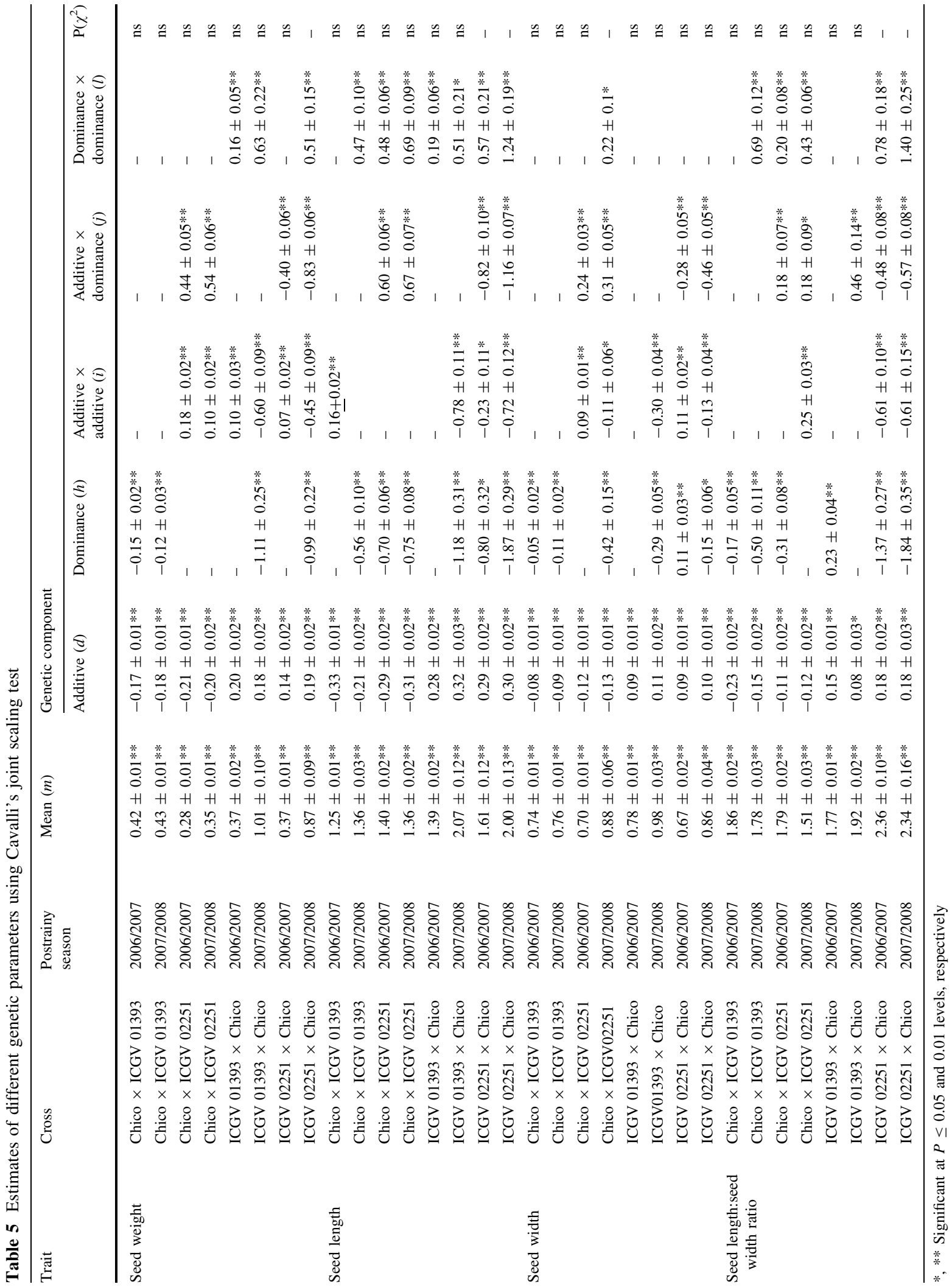




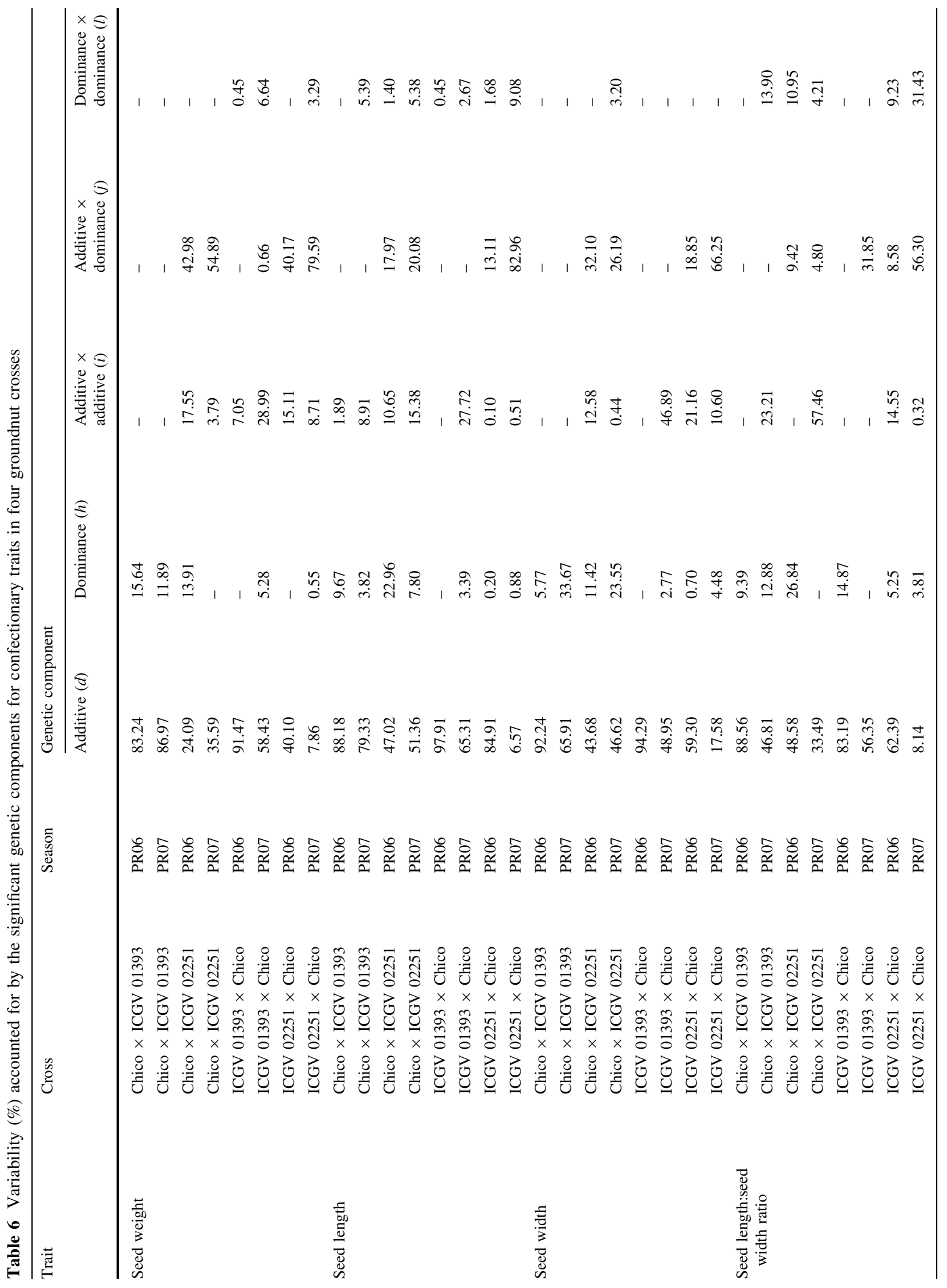


effects could easily be observed in $\mathrm{F}_{1}, \mathrm{~F}_{2}$ and $\mathrm{BC}$ generations; irrespective of the generation smallseeded female gave rise to small seeds and large seeded female yielded large size seeds (Table 1) and the differences were highly significant when generations from reciprocal crosses were compared (Table 2). These findings are consistent with that of de Godoy and Norden (1981), Hammons and Branch (1981), Dwivedi et al. (1989) and Hariprasanna et al. (2008). Groundnut cotyledon and embryonic tissues are a generation ahead of shell (maternal tissue) and according to de Godoy and Norden (1981), maternal influence on seed size is probably due to compaction by the shell. Comparing the means of crosses where female was same (Chico) and different males (Table 1) and from analysis of generation means (Tables 5, 6), it is evident that nuclear genetic effects are also present. These traits appear to be polygenic as seen from segregation in $\mathrm{F}_{2}$ generation and from the significance of mean $(m)$ effects in all the cases (Table 5). Thus, seed size is controlled by combination of both maternal and nuclear gene effects.

All the four seed traits measured in this study are highly correlated among themselves and the correlation is stable across seasons (Table 3 ). This observation suggests that the component traits could be simultaneously improved and separate breeding programs for different components of confectionery trait are not needed. The significance of additive effects in all the four crosses suggests that effective selection for confectionery traits could be practiced even in the early generations. Anderson et al. (1993) too have arrived at similarly conclusion. Hariprasanna et al. (2008) emphasize the importance of parental selection in quality breeding. They indicate that the performance per se of the genotype should be a good indicator of its ability to transmit the desirable quality attributes to its progenies and suggest inclusion of one parent with large seeds in hybridization to obtain better segregants. According to our results, in breeding program, it may be necessary to have the boldseeded parent as the female parent to exploit the maternal effects. This may also be necessary due to the fact that in crosses between small- $\times$ largeseeded parents, small seededness appears to be dominant as seen in this study (Table 1) and others (de Godoy and Norden 1981; Anderson et al. 1993).

\section{References}

Anderson WF, Fitzner MS, Isleib TG, Wynne JC, Phillips TD (1993) Combining ability for large pod and seed traits in peanut. Peanut Sci 20:49-52

Balaiah C, Reddy PS, Reddi MV (1977) Genic analysis in groundnut. I. Inheritance studies on 18 morphological characters in crosses with Gujarat narrow leaf mutant. Proc Indian Acad Sci 85:340-350

Cahaner A (1978) The inheritance of yield components and plant conformation in peanuts, Arachis hypogaea $\mathrm{L}$. $\mathrm{PhD}$ thesis, The Hebrew University, Israel

Cavalli LL (1952) An analysis of linkage in quantitative inheritance. In: Reeve ECR, Waddington $\mathrm{CH}$ (eds) Quantitative inheritance. HMSO, London

de Godoy IJ, Norden AJ (1981) Shell and seed size relationships in peanuts. Peanut Sci 8:21-24

Dwivedi SL, Nigam SN (2005) Confectionery groundnuts: issues and opportunities to promote export and food uses in India. J Oilseeds Res 22:1-4

Dwivedi SL, Thendapani K, Nigam SN (1989) Heterosis and combining ability studies and relationship among fruit and seed characters in peanut. Peanut Sci 16:14-20

Garet B (1976) Heterosis and combining abilities in groundnut (Arachis hypogaea L.). Oleagineux 29:435-442

Hammons RO (1973) Genetics of Arachis hypogaea, pp 135-173. In: Peanuts-culture and uses. American Peanut Research and Education, As-SOC. Inc., Stillwater, OK

Hammons RO, Branch WD (1981) An $F_{2}$ Yield Trial in Peanuts. Peanut Sci 8:53-56

Hariprasanna K, Lal Chuni, Radhakrishnan T, Gor HK, Chikani BM (2008) Analysis of diallel cross for some physical-quality traits in peanut (Arachis hypogaea L.). Euphytica 160:49-57

Layrisse A, Wynne JC, Isleib TG (1980) Combining ability for yield, protein and oil of peanut lines from South American Centers of diversity. Euphytica 29:561-570

Martin JP (1967) Contribution a l'etude de certains caracteres d'importance agronomique chez l'arachide. Oleagineux 22:673-676

Mather K (1949) Biometrical Genetics, 1st edn. Methuen, London

Mather K, Jinks JL (1982) Biometrical Genetics, 3rd edn. Chapman and Hall, London

Mohammed J, Wynne JC, Rawlings JO (1978) Early generation variability and heritability estimates in crosses of Virginia and Spanish peanuts. Oleagineux 33:81-86

Nadaf HL, Habib AF, Patil SS, Sadaqat S (1988) Heterosis and combining ability in groundnut (Arachis hypogaea L.). J Oilseeds Res 5:7-15

Pattanashetti SK, Gowda MVC, Girija (2008) Inheritance of morphological traits and pod features in groundnut (Arachis hypogaea L.). Indian J Genet 68:157-162

Singh RK, Chaudhary BD (1985) Biometrical methods in quantitative genetic analysis. Kalyani Publication, New Delhi

Swe SY, Branch WD (1986) Estimates of combining ability and heterosis among peanut cultivars. Peanut Sci 13: 70-74 
Upadhyaya HD, Gopal K, Nadaf HL, Vijayakumar S (1992) Combining ability studies for yield and its components in groundnut. Indian J Genet 52:1-6

Vindhiya Varman P, Paramasivam K (1992) Genetic architecture of yield and quality characters in groundnut. Madras Agric J 79:688-693
Vindhiya Varman P, Thangavelu S (1999) Genetics and order effects of seed weight in groundnut: a triallel analysis. Indian J Genet 59:95-98 